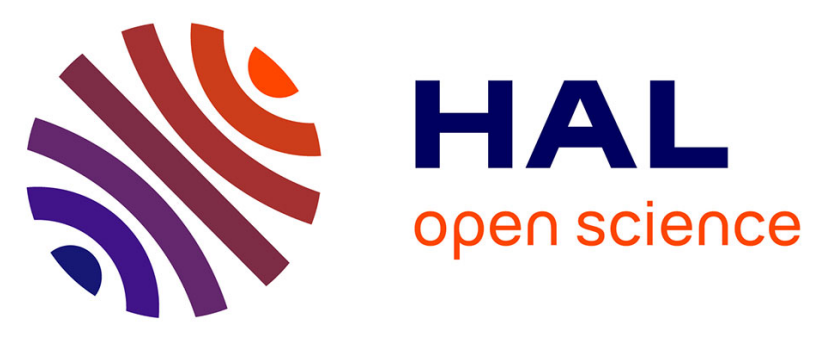

\title{
A multicenter phase I trial of metronomic oral vinorelbine plus cisplatin in patients with NSCLC
}

Athanasios G. Pallis, Vassilis Chandrinos, Georgia Pavlakou, Nikolaos

Xenidis, Ioannis Varthalitis, Nikolaos Vardakis, Lambros Vamvakas, Emmanouel Kontopodis, Maria Rovithi, Vassilis Georgoulias

\section{To cite this version:}

Athanasios G. Pallis, Vassilis Chandrinos, Georgia Pavlakou, Nikolaos Xenidis, Ioannis Varthalitis, et al.. A multicenter phase I trial of metronomic oral vinorelbine plus cisplatin in patients with NSCLC. Cancer Chemotherapy and Pharmacology, 2010, 67 (6), pp.1239-1245. 10.1007/s00280-010-1415-9 . hal-00615338

\section{HAL Id: hal-00615338 \\ https://hal.science/hal-00615338}

Submitted on 19 Aug 2011

HAL is a multi-disciplinary open access archive for the deposit and dissemination of scientific research documents, whether they are published or not. The documents may come from teaching and research institutions in France or abroad, or from public or private research centers.
L'archive ouverte pluridisciplinaire HAL, est destinée au dépôt et à la diffusion de documents scientifiques de niveau recherche, publiés ou non, émanant des établissements d'enseignement et de recherche français ou étrangers, des laboratoires publics ou privés. 
A multicenter phase I trial of metronomic oral Vinorelbine plus Cisplatin in patients with NSCLC

\section{Athanasios G. Pallis ${ }^{\mathrm{a}}$, Vassilis Chandrinos ${ }^{\mathrm{b}}$, Georgia Pavlakou ${ }^{\mathrm{c}}$, Nikolaos Xenidis ${ }^{\mathrm{d}}$, Ioannis Varthalitis ${ }^{\mathrm{e}}$, Nikolaos Vardakis ${ }^{1}$, Lambros Vamvakas ${ }^{\mathrm{a}}$, Emmanouel Kontopodis ${ }^{a}$, Maria Rovithi ${ }^{a}$, Vassilis Georgoulias ${ }^{\mathrm{a}}$}

${ }^{a}$ Department of Medical Oncology, University General Hospital of Heraklion, Crete, Greece

${ }^{b} 2^{\text {nd }}$ Department of Pulmonary Diseases, "Sismanoglion" General Hospital, Penteli, Athens, Greece

${ }^{c} 8^{\text {th }}$ Department of Pulmonary Diseases, "Sotiria" General Hospital, Athens, Greece

${ }^{d}$ Department of Medical Oncology, University General Hospital of Alexandroupolis, Alexandroupolis, Greece

e Department of Medical Oncology, "St. Georgios" General Hospital, Chania, Crete, Greece

Running title: Phase I trial of oral metronomic Vinorelbine plus CDDP in NSCLC

Acknowledgements: This work was finically supported by the Cretan Association for Biomedical Research (CABR).

To whom correspondence should be addressed: V. Georgoulias, $\mathrm{MD}, \mathrm{PhD}$, Department of Medical Oncology, University General Hospital of Heraklion, PO Box 1352, 71110 Heraklion, Crete, Greece.

Tel: +302810392783

Fax: +30.2810392857

E-mail: georgsec@med.uoc.gr 


\begin{abstract}
The purpose of the present study was to determine the maximum tolerated doses (MTDs) and the dose-limiting toxicities of a metronomic administration of oral vinorelbine and cisplatin in patients with advanced/metastatic NSCLC. Twenty-six patients with advanced/metastatic NSCLC were enrolled. Escalating doses of vinorelbine (40-70 mg p.o./trice per week) and cisplatin $\left(70-85 \mathrm{mg} / \mathrm{m}^{2}\right.$ intravenous infusion) were administered on day 1 every 3 weeks. MTDs were reached at $60 \mathrm{mg}$ trice/week p.o. for vinorelbine and $85 \mathrm{mg} / \mathrm{m}^{2}$ for cisplatin. Grade 4 neutropenia, febrile neutropenia, grade 4 diarrhea were the dose-limiting events during the first cycle of chemotherapy. The most common grade III-IV hematologic toxicity was neutropenia occurring in seven $(27 \%)$ patients, while non-hematological toxicities were relatively infrequent and mostly of grade I or II. Objective responses were observed in $20.8 \%$ of patients with measurable disease. The regimen of metronomic administration and cisplatin is feasible and active in patients with NSCLC.
\end{abstract}

Keywords: metronomic, oral Vinorelbine, cipslatin, NSCLC, phase I, maximum tolerated doses, dose-limiting toxicities 


\section{Introduction}

Vinorelbine (VNB) is a semisynthetic analogue of vinblastine that exerts its cytotoxicity via microtubule assembly inhibion $[1,2]$. Vinorelbine is active against a broad range of solid tumors [1]. A new oral form of VNR has been recently developed $[3,4]$ with response and survival results similar to the intravenous agent. A dose of 80 $\mathrm{mg} / \mathrm{m}^{2}$ orally is the equivalent of $30 \mathrm{mg} / \mathrm{m}^{2}$ intravenously, while the oral dose of 60 $\mathrm{mg} / \mathrm{m}^{2}$ is equivalent to $25 \mathrm{mg} / \mathrm{m}^{2}$ iv [4]. Oral VNR has yielded significant activity in advanced non-small-cell lung cancer $[4,5]$. When given at $60 \mathrm{mg} / \mathrm{m}^{2} /$ week for the first three administrations and then at $80 \mathrm{mg} / \mathrm{m}^{2} /$ week, it showed the same efficacy as IV VNR in terms of objective response rate, progression-free survival, and overall survival [5]. The availability of an oral formulation of vinorelbine represents an important advantage in terms of easiness of administration, a very important issue for the treatment of a disease in which palliative intend and quality of life are highly significant issues.

Metronomic administration of cytotoxic drugs is a novel dosing strategy that refers to frequent administration of low doses of chemotherapy over long periods of time, even years, which enhances the anti-endothelial activity of conventional chemotherapeutics, but with lower or no toxic effects compared to maximum tolerated dose administration [6-8]. Among several classes of cytotoxic drugs, microtubulebinding drugs are thought to be one of the most proper for metronomic testing because of their clinically relevant antiangiogenic and vascular-disrupting properties. Furthermore, oral VNB is ideal for metronomic administration because of its convenience of administration. Metronomic administration of VNB has been tested and proved feasible with sustainable antitumor activity without overt toxicity [9]. 
Cisplatin is a key drug in the treatment of NSCLC and cisplatin-based doublets represents the backbone chemotherapy regimen in the front-line treatment of advanced NSCLC. Cisplatin-based chemotherapy regimens are associated with a $27 \%$ reduction in the risk of death and a $10 \%$ absolute improvement in overall survival [10]. The American Society of Clinical Oncology (ASCO) recommends a two-drug combination regimen for first line treatment of advanced NSCLC and states that platinum-based regimens are preferred [11].

Although the combination of oral VNB and cisplatin has been tested in NSCLC $[12,13]$ there is a complete lack of experience concerning the combination of metronomic administration of vinorelbine with standard iv administration of cytotoxic drugs. Other platinum-based metronomic chemotherapy regimens have shown significant efficacy and a very favorable toxicity profile, even in NSCLC patients with poor prognosis [14]. Therefore, a dose-escalating phase I trial was considered to be of interest to confirm the maximum tolerated doses (MTDs) and the dose-limiting toxicities (DLTs) of the combination of metronomic VNB and cisplatin in patients with NSCLC.

\section{Patients and methods}

\section{Patients}

Eligible patients were, aged 18 years or older, with histologically or cytologically confirmed, inoperable locally advanced (stage IIIB with pleural or pericardial effusion) or metastatic (stage IV) NSCLC, with an Eastern Cooperative Oncology Group performance status of 0 -2 [15]. Patients had to have received at least two prior chemotherapy lines (or in the case they had received only one, the oVNB/CDDP should be considered as acceptable treatment by the responsible treating oncologist). 
Prior surgery or radiotherapy ( $\leq 25 \%$ of marrow-containing bones) was allowed, but a treatment-free interval of at least 4 weeks was required before study entry. Patients had to have a life expectancy of more than 3 months and adequate organ function [serum bilirubin $\leq 1.5$ times the upper normal limit (UNL); AST and ALT $\leq 2.5 \mathrm{UNL}$ in the absence of perceptible liver metastases, or $\leq 5$ UNL in the presence of liver metastases; serum creatinine $\leq 1.5$ times the UNL; neutrophils $\geq 1.5 \times 10-9 / \mathrm{L}$, and platelets $\geq 100 \times 10-9 / \mathrm{L}]$. Other eligibility criteria were: absence of active infection, history of significant cardiac disease (unstable angina, congestive heart failure, myocardial infarction within the previous 6 months, ventricular arrhythmias). All patients gave written informed consent to participate in the study and the trial was approved by the Ethics and Scientific Committees of the participating centers. The study was conducted according to the Helsinki Declaration and Good Clinical Practice guidelines [16].

\section{Treatment}

Metronomic VNB was administered per os three times per week (every other day), at escalating doses ranging from $40 \mathrm{gm}$ to $70 \mathrm{mg}$, continuously. Cisplatin was administered iv after adequate hydration, at escalating doses ranging from $70 \mathrm{mg} / \mathrm{m}^{2}$ to $85 \mathrm{mg} / \mathrm{m}^{2}$ on day one, in cycles of three weeks. Standard pre-medication with $16 \mathrm{mg}$ ondasetron iv and post-medication with $8 \mathrm{mg}$ oral ondasetron three times daily for a further 3 days, was used to reduce the risk of nausea/vomiting that can be associated with cisplatin administration.

Treatment was administered on the scheduled days if the absolute neutrophil count was $\geq 1500 / \mathrm{dl}$, platelets $\geq 100,000 / \mathrm{dl}$ and all the other toxicities had resolved to grade $\leq 1$. Otherwise, treatment was postponed for up to seven days until resolution of 
all toxicities. If therapy had to be postponed for more than seven days then doses were reduced to the previous dose levels. Patients requiring a dose reduction due to toxicity (grade IV neutropenia or febrile neutropenia, grade IV thrombocytopenia, and grade IV non-hematological toxicity except alopecia) had the doses of both drugs reduced to the previous dose level. Patients received the reduced dose for the remainder of the study. Patients who had a dose reduction and who experienced toxicity requiring a second dose reduction were taken of study treatment. Prophylactic administration of hematopoietic growth factors was not allowed. Treatment was continued until disease progression, the appearance of unacceptable toxicity, or patient's withdrawal of consent, for a maximum of 6 cycles.

Hematological toxicity was followed weekly with a complete blood cell count including differential and platelet counts; in case of grade 3 or 4 neutropenia, thrombocytopenia or febrile neutropenia, daily blood cell counts were performed until recovery. Blood chemistry and a physical examination were done before each cycle.

\section{Dose Escalation}

The following dose levels have been evaluated for the oVNB/cisplatin combination: $40 / 70,40 / 75,50 / 75,50 / 80,60 / 80,60 / 85$ and 70/85 (Table 2). The maximum-tolerated dose (MTD) was defined as the highest dose at which less than two of six patients experienced a hematologic or non-hematologic treatment-related dose-limiting toxicity (DLT). DLT was defined as the occurrence of the following adverse events (AEs) within the first 21 days of treatment: grade 4 neutropenia lasting for more than 7 consecutive days, febrile neutropenia, or grade 4 thrombocytopenia, or grade $\geq 3$ nonhematologic toxicity, except alopecia. Toxicity was evaluated before each chemotherapy administration and was reported according to the National Cancer 
Institute Common Toxicity Criteria, version 2 [17]. At least three patients in the first cohort were required to have completed one cycle for dose escalation to occur. In the absence of any DLT, three patients entered the next dose level. If one DLT was observed, then three additional patients had to be enrolled to a total of six patients. If two DLTs were observed in six patients, then dosing at the level was stopped, and the MTD was considered exceeded.

\section{Patient evaluation}

Baseline assessment comprised of a complete medical history, evaluation of performance status, physical examination and vital signs, 12-lead ECG, blood tests (complete blood cell count with differential and blood chemistry), chest X-rays and computed tomography (CT) scans of the chest, abdomen and brain and a whole-body radionuclide bone scan. Baseline evaluation had to be performed within two weeks prior to therapy initiation. A complete medical history and a detailed physical examination with complete blood cell count with differential and blood chemistry, ECG and a chest X-ray were performed before each treatment administration to assess the disease status and treatment toxicity. Full blood cell count with differential and platelet counts were performed daily until recovery in case of grade 3-4 hematological toxicity. Response assessment was evaluated every two chemotherapy cycles, and every one month after treatment completion. Objective tumor responses were evaluated according to RECIST criteria [18]. Patients who received at least one cycle were evaluable for safety, while patients who were administered at least two treatment cycles and had bidimensionally measurable disease were evaluable for efficacy. 


\section{Results}

\section{Patient Characteristics}

From 06/2008 to 08/2009, 26 patients with NSCLCs were enrolled into the study. Patient characteristics are presented in Table 1. The median age at enrollment was 64.5 years, most patients $(88.5 \%)$ were male, and $92.3 \%$ had a performance status of $0-1$. Only six patients $(23.1 \%)$ had received prior radiotherapy. All patients received a platinum based doublet as first-line treatment [cisplatin/docetaxel $n=18$ (69\%); cisplatin/gemcitabine $\mathrm{n}=8(31 \%)$ ], while 22 patients $(84.6 \%)$ received second-line treatment [pemetrexed $\mathrm{n}=18(82 \%)$; docetaxel $\mathrm{n}=4(18 \%)$ ]. All patients were evaluable for toxicity.

\section{Dose escalation and MTD}

The dose escalation levels, the number of patients enrolled in each level and the DLTs observed are presented in Table 2. The DLTs observed were grade IV neutropenia $(\mathrm{n}=1$ patient), febrile neutropenia ( $\mathrm{n}=2$ patients) and grade IV neutropenia along with grade IV diarrhea ( $\mathrm{n}=1$ patient). At the 7th dose level, 3 out of 5 patients developed DLTs and therefore this level was considered as the DLT level. The MTDs, which correspond to the doses recommended for future phase II studies, were $60 \mathrm{mg}$ p.o. for vinorelbine three days per week and $85 \mathrm{mg} / \mathrm{m}^{2}$ for cisplatin administered every three weeks.

\section{Dose modifications}

A total of 101 chemotherapy cycles were administered. The median number of cycles per patient was three while the median duration of treatment was 93 days (range:21169). Only 10 cycles $(10 \%)$ were delayed due to toxicity. Delayed hematologic 
recovery was the most frequent reason for delaying treatment. In $16(15.8 \%)$ cycles a dose reduction was required due to toxicity. Six (5.9\%) cycles were given at a reduced dose due to hematological toxicity, three cycles $(3.0 \%)$ due to non-hematological toxicity, and seven (7.0\%) for both hematological and non-hematological toxicity. Three patients (11.5\%) discontinued treatment due to an adverse event and one patient $(3.8 \%)$ withdrew consent.

\section{Toxicity}

Tables 3 and 4 list the hematological and non-hematological toxicities (by dose level and by grade) that were at least possibly related to treatment occurring in more than $10 \%$ of total cycles. The most frequent grade III-IV hematological toxicity was neutropenia which occurred in seven $(27 \%)$ patients, while non-hematological toxicities were relatively infrequent and mostly grade I or II.

\section{Antitumor activity}

Among the 24 patients who were evaluable for response, no patient had a complete response, while five patients achieved a partial response as their best response, for an overall response rate of $20.8 \%$ (95\% CI: $4.59 \%-37.08 \%$ ). Ten patients (41.7\%) achieved stable disease and nine (37.5\%) progressive disease. Responses were observed at the $2^{\text {nd }}(\mathrm{n}=1$ patient $), 3^{\text {rd }}(\mathrm{n}=1$ patient $), 4^{\text {th }}(\mathrm{n}=1$ patient $), 5^{\text {th }}(\mathrm{n}=1$ patient $)$, and $6^{\text {th }}(\mathrm{n}=1$ patient $)$ dose levels.

\section{Discussion}

Metronomic chemotherapy is the continuous low-dose and dense administration of cytotoxic drugs aiming to avoid dose-limiting toxicities [19]. This treatment strategy 
exerts its antitumor activity by inhibiting endothelial cell proliferation which, subsequently, results to decreased angiogenesis [20]. This therapeutic strategy may have several advantages in clinical practice, such as a favorable toxicity profile and treatment response regardless of the resistance profile of the cancer cell $[21,22]$. Indeed, several clinical studies have provided evidence supporting the feasibility and activity of the metronomic treatment $[8,23,24]$. Since antimitotics are thought to be the most appropriate drugs for metronomic use [25, 26], vinorelbine is an ideal candidate for metronomic therapy; in addition, vinorelbine is available in oral formulation, which is very convenient for chronic metronomic administration. A recent report clearly demonstrated that oral vinorelbine serves very well the concept of metronomic therapy with a very favorable toxicity profile and significant antitumor activity [9]. The results of the current phase I study demonstrated that metronomic vinorelbine in combination with cisplatin is feasible and active against NSCLC; in addition, the study defined that the recommended doses for a future phase II study are $60 \mathrm{mg}$ for oral vinorelbine, thrice/week (every other day) and $85 \mathrm{mg} / \mathrm{m}^{2}$ for cisplatin, on day 1 , in cycles of three weeks.

The cisplatin/vinorelbine doublet is a well studied and active doublet in the treatment of NSCLC either in the adjuvant $[27,28]$ or in the advanced disease setting [29-31]. On the other hand, this combination is very toxic with severe neutropenia occurring in more than $40 \%-80 \%$ of the patients $[27,29,31]$. Thus, we considered of interest a study evaluating the combination of metronomic administration of vinorelbine with cisplatin, a strategy which is likely to have a more favorable toxicity profile. Indeed, the results of the current study demonstrated that the metronomic oral vinorelbine-cisplatin doublet was very well tolerated with only $27 \%$ of patients developing grade III-IV neutropenia. Moreover, the fact that only $16(15.8 \%)$ cycles 
required a dose reduction further proves the very favorable toxicity profile of this combination. A similar observation was reported by Briasoulis et al [9] who yielded that metronomic administration of oral vinorelbine is feasible without overt toxicity. The fact that a similar toxicity profile was observed between the current study and the study by Briasoulis et al [9] suggests that cisplatin addition to vinorelbine did not alter significantly the toxicity profile of metronomic vinorelbine, at least in the population studied.

Another important issue is the efficacy of this combination. The response rate was $20.8 \%$ with another $41.7 \%$ of the patients experiencing a stable disease for a disease control rate of $62.5 \%$, which is encouraging for this group of patients. Thus, this combination merits further assessment in the context of a phase II trial.

In conclusion the findings of this phase I study can be added to the growing bank of evidence for the usefulness of metronomic treatment in combination with standard drug administration. The combination of metronomic oral vinorelbine with cisplatin is feasible, well tolerated and active in the treatment of NSCLC, and merits further investigation in the context of a phase II trial.

\section{Conflict of interest}

The authors declare that they do not have any conflict of interest 


\section{References}

1. Goa KL, Faulds D. (1994). Vinorelbine. A review of its pharmacological properties and clinical use in cancer chemotherapy. Drugs Aging. 5: 200-234.

2. Potier P. (1989). The synthesis of Navelbine prototype of a new series of vinblastine derivatives. Semin.Oncol. 16: 2-4.

3. Marty M, Fumoleau P, Adenis A, Rousseau Y, Merrouche Y, Robinet G, Senac I, Puozzo C. (2001). Oral vinorelbine pharmacokinetics and absolute bioavailability study in patients with solid tumors. Ann Oncol. 12: 1643-1649.

4. Gralla RJ, Gatzemeier U, Gebbia V, Huber R, O'Brien M, Puozzo C. (2007). Oral vinorelbine in the treatment of non-small cell lung cancer: rationale and implications for patient management. Drugs. 67: 1403-1410.

5. Jassem J, Ramlau R, Karnicka-Mlodkowska H, Krawczyk K, Krzakowski M, Zatloukal P, Lemarie E, Hartmann W, Novakova L, O'Brien M, Depierr A. (2001). A multicenter randomized phase II study of oral vs. intravenous vinorelbine in advanced non-small-cell lung cancer patients. Ann Oncol. 12: $1375-1381$.

6. Hanahan D, Bergers G, Bergsland E. (2000). Less is more, regularly: metronomic dosing of cytotoxic drugs can target tumor angiogenesis in mice. J Clin Invest. 105: 1045-1047.

7. Kerbel RS, Klement G, Pritchard KI, Kamen B. (2002). Continuous low-dose anti-angiogenic/ metronomic chemotherapy: from the research laboratory into the oncology clinic. Ann Oncol. 13: 12-15.

8. Kerbel RS, Kamen BA. (2004). The anti-angiogenic basis of metronomic chemotherapy. Nat.Rev.Cancer. 4: 423-436. 
9. Briasoulis E, Pappas P, Puozzo C, Tolis C, Fountzilas G, Dafni U, Marselos M, Pavlidis N. (2009). Dose-ranging study of metronomic oral vinorelbine in patients with advanced refractory cancer. Clin Cancer Res. 15: 6454-6461.

10. (1995). Chemotherapy in non-small cell lung cancer: a meta-analysis using updated data on individual patients from 52 randomised clinical trials. Non-small Cell Lung Cancer Collaborative Group. BMJ. 311: 899-909.

11. Azzoli CG, Baker S Jr, Temin S, Pao W, Aliff T, Brahmer J, Johnson DH, Laskin JL, Masters G, Milton D, Nordquist L, Pfister DG, Piantadosi S, Schiller JH, Smith R, Smith TJ, Strawn JR, Trent D, Giaccone G. (2009). American Society of Clinical Oncology Clinical Practice Guideline Update on Chemotherapy for Stage IV Non-Small-Cell Lung Cancer. J Clin Oncol.

12. Jassem J, Kosmidis P, Ramlau R, Zarogoulidis K, Novakova L, Breton J, Etienne PL, Seebacher C, Grivaux M, Ojala A, Aubert D, Lefresne F. (2003). Oral vinorelbine in combination with cisplatin: a novel active regimen in advanced non-small-cell lung cancer. Ann Oncol. 14: 1634-1639.

13. Chen YM, Yu CJ, Yang CH, Perng RP, Tsai CM, Shih JF, Cheng AL, Lefresne F, Barbier M, Pouget JC, Yang PC. (2007). A phase II study of oral vinorelbine in combination with cisplatin conducted in Taiwan in patients with unresectable localized or metastatic non-small cell lung carcinoma. Lung Cancer. 56: 89-95.

14. Correale P, Cerretani D, Remondo C, Martellucci I, Marsili S, La PM, Sciandivasci A, Paolelli L, Pascucci A, Rossi M, Di BM, Giorgi G, Gotti G, Francini G. (2006). A novel metronomic chemotherapy regimen of weekly platinum and daily oral etoposide in high-risk non-small cell lung cancer patients. Oncol Rep. 16: 133-140. 
15. Oken MM, Creech RH, Tormey DC, Horton J, Davis TE, McFadden ET, Carbone PP. (1982). Toxicity and response criteria of the Eastern Cooperative Oncology Group. Am J Clin Oncol. 5: 649-655.

16. ICH Efficacy Guidelines.E6(R1). (2009). Good Clinical Practice: Consolidated Guideline. http://www.ich.org/cache/compo/475-272-1.html.

17. Cancer Therapy Evaluation Program. (1998). Common toxicity criteria. Version 2.0. DCTD, NCI, NIH, DHHS.

18. Therasse P, Arbuck SG, Eisenhauer EA, Wanders J, Kaplan RS, Rubinstein L, Verweij J, Van GM, van Oosterom AT, Christian MC, Gwyther SG. (2000). New guidelines to evaluate the response to treatment in solid tumors. European Organization for Research and Treatment of Cancer, National Cancer Institute of the United States, National Cancer Institute of Canada. JNCI Cancer Spectrum. 92: 205-216.

19. Bocci G, Nicolaou KC, Kerbel RS. (2002). Protracted low-dose effects on human endothelial cell proliferation and survival in vitro reveal a selective antiangiogenic window for various chemotherapeutic drugs. Cancer Res. 62: 6938-6943.

20. Hirata S, Matsubara T, Saura R, Tateishi H, Hirohata K. (1989). Inhibition of in vitro vascular endothelial cell proliferation and in vivo neovascularization by lowdose methotrexate. Arthritis Rheum. 32: 1065-1073.

21. Hermans IF, Chong TW, Palmowski MJ, Harris AL, Cerundolo V. (2003). Synergistic effect of metronomic dosing of cyclophosphamide combined with specific antitumor immunotherapy in a murine melanoma model. Cancer Res. 63: 8408-8413. 
22. Glode LM, Barqawi A, Crighton F, Crawford ED, Kerbel R. (2003). Metronomic therapy with cyclophosphamide and dexamethasone for prostate carcinoma. Cancer. 98: 1643-1648.

23. Colleoni M, Orlando L, Sanna G, Rocca A, Maisonneuve P, Peruzzotti G, Ghisini R, Sandri MT, Zorzino L, Nole F, Viale G, Goldhirsch A. (2006). Metronomic low-dose oral cyclophosphamide and methotrexate plus or minus thalidomide in metastatic breast cancer: antitumor activity and biological effects. Ann Oncol. 17: 232-238.

24. Bottini A, Generali D, Brizzi MP, Fox SB, Bersiga A, Bonardi S, Allevi G, Aguggini S, Bodini G, Milani M, Dionisio R, Bernardi C, Montruccoli A, Bruzzi P, Harris AL, Dogliotti L, Berruti A. (2006). Randomized phase II trial of letrozole and letrozole plus low-dose metronomic oral cyclophosphamide as primary systemic treatment in elderly breast cancer patients. J Clin Oncol. 24: $3623-3628$.

25. Schwartz EL. (2009). Antivascular actions of microtubule-binding drugs. Clin Cancer Res. 15: 2594-2601.

26. Kruczynski A, Poli M, Dossi R, Chazottes E, Berrichon G, Ricome C, Giavazzi R, Hill BT, Taraboletti G. (2006). Anti-angiogenic, vascular-disrupting and antimetastatic activities of vinflunine, the latest vinca alkaloid in clinical development. Eur.J Cancer. 42: 2821-2832.

27. Douillard JY, Rosell R, De LM, Carpagnano F, Ramlau R, Gonzales-Larriba JL, Grodzki T, Pereira JR, Le GA, Lorusso V, Clary C, Torres AJ, Dahabreh J, Souquet PJ, Astudillo J, Fournel P, rtal-Cortes A, Jassem J, Koubkova L, His P, Riggi M, Hurteloup P. (2006). Adjuvant vinorelbine plus cisplatin versus observation in patients with completely resected stage IB-IIIA non-small-cell lung 
cancer (Adjuvant Navelbine International Trialist Association [ANITA]): a randomised controlled trial. Lancet Oncol. 7: 719-727.

28. Arriagada R, Bergman B, Dunant A, Le CT, Pignon JP, Vansteenkiste J. (2004). Cisplatin-based adjuvant chemotherapy in patients with completely resected nonsmall-cell lung cancer. N.Engl.J Med. 350: 351-360.

29. Georgoulias V, Ardavanis A, Tsiafaki X, Agelidou A, Mixalopoulou P, Anagnostopoulou O, Ziotopoulos P, Toubis M, Syrigos K, Samaras N, Polyzos A, Christou A, Kakolyris S, Kouroussis C, Androulakis N, Samonis G, Chatzidaki D. (2005). Vinorelbine plus cisplatin versus docetaxel plus gemcitabine in advanced non-small-cell lung cancer: a phase III randomized trial. J Clin Oncol. 23: 2937 2945.

30. Pirker R, Pereira JR, Szczesna A, von PJ, Krzakowski M, Ramlau R, Vynnychenko I, Park K, Yu CT, Ganul V, Roh JK, Bajetta E, O'Byrne K, de MF, Eberhardt W, Goddemeier T, Emig M, Gatzemeier U. (2009). Cetuximab plus chemotherapy in patients with advanced non-small-cell lung cancer (FLEX): an open-label randomised phase III trial. Lancet. 373: 1525-1531.

31. Tan EH, Rolski J, Grodzki T, Schneider CP, Gatzemeier U, Zatloukal P, Aitini E, Carteni G, Riska H, Tsai YH, Abratt R. (2009). Global Lung Oncology Branch trial 3 (GLOB3): final results of a randomised multinational phase III study alternating oral and i.v. vinorelbine plus cisplatin versus docetaxel plus cisplatin as first-line treatment of advanced non-small-cell lung cancer. Ann Oncol. 20: $1249-1256$. 
Table 1 Patients' characteristics

\begin{tabular}{|c|c|c|}
\hline & No Pts $(n=26)$ & $\%$ \\
\hline Age->Median (Min - Max) & 64.50 & $36-80$ \\
\hline \multicolumn{3}{|l|}{ Sex } \\
\hline Male & 23 & 88.5 \\
\hline Female & 3 & 11.5 \\
\hline \multicolumn{3}{|l|}{ Stage } \\
\hline IV & 18 & 69.2 \\
\hline$I I I B$ & 8 & 30.8 \\
\hline \multicolumn{3}{|l|}{ Performance status } \\
\hline 0 & 8 & 30.8 \\
\hline 1 & 16 & 61.5 \\
\hline 2 & 2 & 7.7 \\
\hline \multicolumn{3}{|l|}{ Histology } \\
\hline Squamous & 11 & 42.3 \\
\hline Adeno $\mathrm{Ca}$ & 9 & 34.6 \\
\hline Mixed & 1 & 3.8 \\
\hline Other & 5 & 19.2 \\
\hline \multicolumn{3}{|l|}{ no of organs involved } \\
\hline 0 & 2 & 7.7 \\
\hline 1 & 2 & 7.7 \\
\hline 2 & 7 & 26.9 \\
\hline 3 & 9 & 34.6 \\
\hline 4 & 2 & 7.7 \\
\hline 5 & 3 & 11.5 \\
\hline 6 & 1 & 3.8 \\
\hline Median (Min-Max) & 3 & $0-6$ \\
\hline \multicolumn{3}{|l|}{ Smoking Status } \\
\hline Active smoker & 15 & 57.7 \\
\hline Non-active smoker & 9 & 34.6 \\
\hline Unknown & 2 & 7.7 \\
\hline \multicolumn{3}{|l|}{ Prior Therapy } \\
\hline RT & 6 & 23.1 \\
\hline 1st line (platinum-based doublet) & 26 & 100 \\
\hline 2nd line (docetaxel/pemetrexed) & 22 & 84.6 \\
\hline
\end{tabular}


Table 2 Dose levels and DLTs observed at each dose level

\begin{tabular}{|c|c|c|c|c|}
\hline Dose Level & $\mathbf{n}$ & $\begin{array}{c}\text { Vinorelbine } \\
\text { (mg per os; } 3 \\
\text { days per } \\
\text { week) }\end{array}$ & $\begin{array}{c}\text { Cisplatin } \\
\text { (mg/m², d1, } \\
\text { q21 days) }\end{array}$ & \\
\hline I & 3 & 40 & 70 & - \\
\hline II & 3 & 40 & 75 & - \\
\hline III & 3 & 50 & 75 & - \\
\hline IV & 3 & 50 & 80 & - \\
\hline $\mathrm{V}$ & 3 & 60 & 80 & - \\
\hline VI & 6 & 60 & 85 & Febrile neutropenia $\mathrm{n}=1$ \\
\hline VII & 5 & 70 & 85 & $\begin{array}{c}\text { Febrile neutropenia } n=1 \\
\text { Grade IV neutropenia } n=1 \\
\text { Grade IV neutropenia and } \\
\text { grade IV diarrhea } n=1\end{array}$ \\
\hline
\end{tabular}


Table 3 Hematological toxicity by treatment level

\begin{tabular}{|c|c|c|c|c|c|c|c|c|c|c|}
\hline \multirow[b]{2}{*}{$\begin{array}{c}\text { Level/ } \\
\text { No of Cy } \\
\end{array}$} & \multirow[b]{2}{*}{$\begin{array}{c}\text { VNB (p.o. } \\
3 \text { days per } \\
\text { week) }\end{array}$} & \multirow[b]{2}{*}{$\begin{array}{c}\text { Cisplatin } \\
\left(\mathbf{m g} / \mathbf{m}^{2}\right)\end{array}$} & \multicolumn{3}{|c|}{$\begin{array}{l}\text { Neutropenia } \\
\mathbf{N}(\%) \\
\end{array}$} & \multicolumn{3}{|c|}{$\begin{array}{c}\text { Anemia } \\
\mathbf{N}(\%)\end{array}$} & \multicolumn{2}{|c|}{$\begin{array}{c}\text { Febrile neutropenia } \\
\text { N(\%) }\end{array}$} \\
\hline & & & Grade II & Grade III & Grade IV & Grade II & Grade III & Grade IV & Grade II & Grade IV \\
\hline $1 / 12$ & $40 \times 3$ & 70 & $\begin{array}{c}1 \\
(8.3)\end{array}$ & - & - & - & - & - & - & - \\
\hline $2 / 14$ & $40 \times 3$ & 75 & - & - & - & $\begin{array}{c}1 \\
(7.1) \\
\end{array}$ & $\begin{array}{c}1 \\
(7.1)\end{array}$ & $\begin{array}{c}1 \\
(7.1) \\
\end{array}$ & - & - \\
\hline $3 / 15$ & $50 \times 3$ & 75 & $\begin{array}{c}1 \\
(6.7)\end{array}$ & - & - & - & - & - & - & - \\
\hline $4 / 15$ & $50 \times 3$ & 80 & - & - & - & $4(6.7)$ & - & - & - & - \\
\hline $5 / 10$ & $60 \times 3$ & 80 & - & $1(10.0)$ & - & - & - & - & - & - \\
\hline $6 / 26$ & $60 \times 3$ & 85 & $2(7.7)$ & $\begin{array}{c}1 \\
(3.8) \\
\end{array}$ & $\begin{array}{c}3 \\
(11.5) \\
\end{array}$ & $\begin{array}{c}3 \\
(11.5) \\
\end{array}$ & - & - & $\begin{array}{c}1 \\
(3.8) \\
\end{array}$ & $\begin{array}{c}1 \\
(3.8) \\
\end{array}$ \\
\hline $7 / 9$ & $70 \times 3$ & 85 & - & $\begin{array}{c}1 \\
(11.1)\end{array}$ & $2(22.2)$ & $1(11.1)$ & - & - & - & $\begin{array}{c}1 \\
(11.1)\end{array}$ \\
\hline
\end{tabular}


Table 4 Non-hematological toxicity by treatment level

\begin{tabular}{|c|c|c|c|c|c|c|c|c|c|c|c|c|c|c|c|c|}
\hline \multirow[b]{2}{*}{$\begin{array}{l}\text { Level/ No } \\
\text { of Cy }\end{array}$} & \multirow[b]{2}{*}{$\begin{array}{c}\text { VNB } \\
\text { (p.o. 3 } \\
\text { days } \\
\text { per } \\
\text { week) } \\
\end{array}$} & \multirow[b]{2}{*}{$\underset{\left(\mathbf{m g} / \mathbf{m}^{2}\right)}{\text { Cisplatin }}$} & \multicolumn{2}{|c|}{$\begin{array}{c}\text { Nausea/Vomiting } \\
\mathbf{N}(\%)\end{array}$} & \multicolumn{3}{|c|}{$\begin{array}{c}\text { Diarrhea } \\
\mathbf{N}(\%)\end{array}$} & \multirow{2}{*}{$\begin{array}{c}\begin{array}{c}\text { Mucositis } \\
\text { N(\%) }\end{array} \\
\begin{array}{c}\text { Grade } \\
\text { II }\end{array}\end{array}$} & \multicolumn{2}{|c|}{$\begin{array}{c}\text { Constipation } \\
\mathrm{N}(\%)\end{array}$} & \multicolumn{3}{|c|}{$\begin{array}{c}\text { Neurotoxicity } \\
\mathbf{N}(\%)\end{array}$} & \multicolumn{3}{|c|}{$\begin{array}{l}\text { Fatigue } \\
\mathrm{N}(\%)\end{array}$} \\
\hline & & & $\begin{array}{c}\text { Grade } \\
\text { II }\end{array}$ & $\begin{array}{l}\text { Grade } \\
\text { III }\end{array}$ & $\begin{array}{l}\text { Grade } \\
\text { II }\end{array}$ & $\begin{array}{c}\text { Grade } \\
\text { III }\end{array}$ & $\begin{array}{l}\text { Grade } \\
\text { IV }\end{array}$ & & $\begin{array}{l}\text { Grade } \\
\text { III }\end{array}$ & $\begin{array}{l}\text { Grade } \\
\text { IV }\end{array}$ & $\begin{array}{c}\text { Grade } \\
\text { II }\end{array}$ & $\begin{array}{c}\text { Grade } \\
\text { III }\end{array}$ & $\begin{array}{c}\text { Grade } \\
\text { IV }\end{array}$ & $\begin{array}{c}\text { Grade } \\
\text { II }\end{array}$ & $\begin{array}{l}\text { Grade } \\
\text { III }\end{array}$ & $\underset{\text { IV }}{\text { Grade }}$ \\
\hline $1 / 12$ & 40 & 70 & - & - & - & - & - & - & - & - & - & - & - & - & - & - \\
\hline $2 / 14$ & 40 & 75 & $2(11.1)$ & - & - & - & - & - & - & - & - & - & - & - & - & - \\
\hline $3 / 15$ & 50 & 75 & $\begin{array}{c}1 \\
(6.7)\end{array}$ & $\begin{array}{c}1 \\
(6.7)\end{array}$ & - & - & - & - & - & - & - & - & - & - & $\begin{array}{c}1 \\
(6.7) \\
\end{array}$ & - \\
\hline $4 / 15$ & 50 & 80 & - & - & - & - & - & - & $\begin{array}{c}1 \\
(6.7)\end{array}$ & - & - & - & $1(2.0)$ & - & - & - \\
\hline $5 / 10$ & 60 & 80 & $\begin{array}{c}2 \\
(20.0)\end{array}$ & - & $\begin{array}{c}1 \\
(10.0)\end{array}$ & - & - & - & - & - & - & - & - & $\begin{array}{c}4 \\
(40.0) \\
\end{array}$ & - & - \\
\hline $6 / 26$ & 60 & 85 & $\begin{array}{c}2 \\
(7.7)\end{array}$ & - & $\begin{array}{c}3 \\
(11.5) \\
\end{array}$ & - & - & $\begin{array}{c}1 \\
(3.8)\end{array}$ & - & - & - & - & - & $4(40.0)$ & - & - \\
\hline $7 / 9$ & 70 & 85 & $\begin{array}{c}1 \\
(11.1)\end{array}$ & - & $\begin{array}{c}1 \\
(11.1)\end{array}$ & - & $\begin{array}{c}1 \\
(11.1)\end{array}$ & - & - & - & - & - & - & $\begin{array}{c}1 \\
(11.1)\end{array}$ & $\begin{array}{c}1 \\
(11.1)\end{array}$ & - \\
\hline
\end{tabular}

